\title{
TAX CODE REVISION AND THE VALUE OF TAX-DEDUCTIBLE DEBT
}

\author{
William Lewis Randolph \\ Norfolk State University \\ Norfolk, VA
}

\begin{abstract}
This paper examines a tax policy change that would eliminate the interest expense as a tax-deductible item for businesses. We analyze this change using a tax revenue neutral setting in a Modigliani-Miller world. The analysis uses two scenarios to compare the change to the present U.S. Tax Code. Scenario one assumes a non-competitive environment with sticky prices. Scenario two assumes that companies or industries with low leverage would cut prices instead of realizing excess profits. The reduction in prices will redistribute the present value of the corporate tax shield from the stockholder to the consumer. Using the Modigliani-Miller methodology for valuation, the maximum value (equivalent to theoretical value in this case) of the tax shield is approximately $\$ 712$ billion. The actual value is probably less than half the theoretical amount. Under either scenario, the weighted average cost of capital increases for levered firms.
\end{abstract}

\section{Introduction}

For business owners an important feature of the U.S. Tax Code is the policy that allows business interest expense to be tax deductible. Modigliani and Miller (1963) have shown that tax-deductible interest expense adds value to the firm when debt is used in the capital structure. Several changes to the Tax Code have been proposed that would eliminate this important deduction. These proposals include the flat-tax, value added tax (VAT), and a national sales tax. Sullivan (1995) examines these tax proposals in detail but does not address the loss in value from the elimination of tax-deductible business debt. This paper examines the effects of a corporate tax policy under which interest expense is not tax deductible. This change could be the result of either the elimination of corporate taxes or a modification in the corporate tax code.

A tax code change that eliminates the firm value added by tax deductible debt would be of strategic importance to investors and business managers. Considering the theoretical relationship between firm value, leverage, and taxes developed by Modigliani and Miller (1963), a tax code change of this type will have an impact on relative firm valuation that will directly impact stock prices. This change will also affect capital structure decisions and could impact capital budgeting decisions because of potential cost of capital changes. 
We examine this issue by analyzing a tax system change that eliminates the tax deductibility of interest expense while keeping total corporate tax revenue constant. The externalities associated with the current tax system would undergo changes if interest expenses were no longer deductible. The most important change would be the loss of the value of the tax shield to the owners of the business. But wealth is neither created nor destroyed by changing the tax code, it is merely redistributed. We show in our findings that in a perfectly competitive economy the value of the tax shield is redistributed back to the consumer through lower prices.

This change in the tax code will also affect the cost of capital for firms that use debt. Since the use of tax-deductible interest expenses increases the value of the firm, the cost of capital of the firm can be reduced by using debt. Firms using debt would have their cost of capital increase if the change is considered in isolation. An increase in the cost of capital would tend to put U.S. firms at a competitive disadvantage in international markets. Other aspects of some of the proposed tax changes - such as making dividend payments and capital gains nontaxable for investors - would reduce the cost of capital and help offset increases from the loss of the interest expense deduction.

Another factor we examine is the effect of the tax code change on the risk associated with debt repayment. The risk associated with a claim on the firm's cash flow is inversely related to the priority of the claim on the earnings stream of the firm. Under the current tax system, interest payments to lenders have priority over corporate income taxes since interest expense is deducted before taxes are computed. This makes the lenders' claim less risky in comparison to a tax code change that results in interest expenses not being deductible.

If business interest expenses become nondeductible, this change will have an differing impact on firms with different capital structures. The firm with low financial leverage could benefit from this change while the highly levered firm would not benefit. We show in the findings how the change would impact the stock prices of firms with different amounts of leverage. This factor is of critical importance to financial analysts and the investing public.

\section{Corporate Valuation}

The Modigliani-Miller $(1958,1963)$ analysis of the effect of capital structure on the cost of capital forms the basis for our analysis. We use the standard Modigliani-Miller (MM) assumptions that assume, among other things, that all firms are in the same risk class and that firms issue only two types of claims; riskfree debt and risky equity. For a complete list of assumptions and a detailed presentation of the MM analysis, see Copeland and Weston (1988). The MM Proposition I, modified for tax-deductible corporate debt, holds that the value of the levered firm, $\mathrm{Vl}$, is equal to the value of an unlevered firm, $\mathrm{Vu}$, plus the present value of the tax shield provided by debt, $\mathrm{tD}$. We have 


$$
V l=V u+t D,
$$

where $t$ is the corporate tax rate and $D$ is the amount of debt used.

If the corporate tax code were to be changed where interest expenses related to corporate debt were no longer tax-deductible then we would have

$$
v l=V u \text {. }
$$

The present value of the tax shield that belonged to the owners of the firm is lost. The source of the added value is usually not addressed in finance literature, but, as we will demonstrate, this value is redistributed to the consumer in a perfectly competitive economic system.

The MM Proposition II states that the expected return on a share of stock is equal to the appropriate capitalization rate, $r$, for an unlevered stock plus a premium related to financial risk equal to the debt-to-equity ratio $(B / S)$ times the difference between $r$ and the cost of borrowing, $\mathrm{kb}$. Adjusted for taxes, the return on equity, ks, can be computed using

$$
k s=r+(I-t)(r-k b)(B / S) \text {. }
$$

One of the great contributions of the MM papers was the demonstration that the cost of capital for the firm was invariant to capital structure in the absence of tax effects. But since the interest expense on corporate debt is tax-deductible, the cost of capital can be reduced by using debt in the capital structure. The weighted average cost of capital (WACC) is computed using

$$
W A C C=(I-t) k b[B /(B+S)]+k s[S /(B+S)] .
$$

\section{Analysis}

\section{Assumptions and Methodology}

To analyze the effects of tax policy change, we assume that any changes made in the tax code will be revenue neutral. Thus, the total taxes collected after the change will equal the total taxes collected before the change. This assumption allows the analysis to focus on the impact of this change alone. If interest expenses are no longer tax-deductible the taxable income would increase. To maintain revenue neutrality, we reduce the tax rate so the government collects the same amount of tax revenue after the change. Since firms use different amounts of debt in their capital structure, the reduction in the tax rate will affect firms differently. After the change, firms with below average amounts of debt will pay less tax. Firms with higher than average debt will pay more tax. Firms with an average amount of debt would find their corporate income tax unchanged. The change would benefit firms that use little debt and hurt firms that use higher than average amounts of debt.

The economic behavior of firms who pay lower taxes as a result of the change is a critical factor in the analysis. We use two scenarios to examine the change under competitive and non-competitive economic environments.. In the first scenario, we assume a non-competitive environment. In this environment, prices are sticky and do not change when we reduce the tax rate. Since prices do not change, 
total corporate sales and total earnings for the three firms will be the same as under the current tax policy (the base case). In this scenario, the no-leverage firm receives an earnings increase, the high-leverage firm receives an equal earnings decrease, and the average-leverage firm has constant earnings. In the second scenario, we assume competition. Competitive pressure from firms with belowaverage leverage would lead to price cuts rather than windfall profits. Under either scenario, the value of firms that are identical except for leverage becomes equal after the tax code change. Their tax bills also become equal. When the distortion caused by the tax system is removed or changed, firms with identical functions and levels of sales would have the same value and pay the same tax.

What happens to the value of the tax shield, $t D$ ? In the examples below, we show that in the non-competitive scenario high leverage firms lose value to low leverage firms. Under perfect competition, the consumer receives the value of the tax shield as price reductions.

We analyze the effect that this change in the tax code has on investors. We do this by examining changes in the risk/return characteristics of the securities of the corporation. We examine changes in stock prices and the return on equity (ROE) which will affect shareholders. We also show how the change could affect risky debt. An important risk indicator for bondholders is the times-interest earned or coverage ratio. The coverage ratio is the amount of earnings available for debt service divided by the amount of the interest expense. High coverage ratios mean less risk for the bondholders.

\section{The Example}

It is straight forward to show the loss of the tax if interest expenses are not tax-deductible. It is also evident that stockholders of highly levered firms will suffer losses on their investment in these firms. To show what happens to this value is more complicated. If some stockholders will be worse off, who will benefit? We have outlined the answer to this question above. We use an example to demonstrate the logic of these answers. The example details the flow of funds that would occur due to the change in the tax code.

In the following example we use three firms that differ only in capital structure to demonstrate the ramifications of making interest expenses non-deductible. One company uses no debt in its capital structure, another company uses a relatively large amount of debt, and the third company uses an average amount of debt. We assume a Modigliani-Miller world with corporate taxes.

The unlevered company, NOLEVCO, has a net income (also cash flow) of $\$ 187.50$ and the appropriate capitalization rate or discount rate, $r$, is $12.5 \%$. Since the company is unlevered, the cost of capital and ROE are also $12.5 \%$. This results in $\$ 1500$ value for NOLEVCO and, because the company has 150 shares outstanding, the market value of a share is $\$ 10.00$. The pre-change corporate tax rate is $25 \%$. The first column of Table 1 presents the base case financial data for NOLEVCO. 
Table 1

NOLEVCO Financial Data

\begin{tabular}{|c|c|c|c|c|c|}
\hline \multicolumn{6}{|c|}{ Income Statement } \\
\hline \multirow{2}{*}{\multicolumn{2}{|c|}{$\begin{array}{c}\text { Current Policy } \\
\text { Tax Deductible Interest }\end{array}$}} & \multirow{2}{*}{\multicolumn{4}{|c|}{$\begin{array}{l}\text { Nondeductible Interest Expense } \\
\text { Scenario } 1\end{array}$}} \\
\hline & & & & & \\
\hline Sales & \multirow{2}{*}{$\begin{array}{r}\$ 1,000.00 \\
(750.00) \\
\end{array}$} & Sales & $\$ 1,000.00$ & Sales & $\$ 987.50$ \\
\hline Costs & & Costs & $(750.00)$ & Costs & $(750.00)$ \\
\hline Op. Pr. & 250.00 & Op. Pr. & 250.00 & Op. Pr. & 237.50 \\
\hline Int. Exp. & 0.00 & Tax (@20\%) & $(50.00)$ & $\operatorname{Tax}(@ 21 \%)$ & $(50.00)$ \\
\hline E. B. Tax & 250.00 & E. A. Tax & 200.00 & E. A. Tax & 187.50 \\
\hline $\operatorname{Tax}(@ 25 \%)$ & $(62.50)$ & Int. Exp. & 0.00 & Int. Exp. & 0.00 \\
\hline N. I. & 187.50 & N. I. & 200.00 & N. I. & 187.50 \\
\hline \multicolumn{6}{|c|}{ Values and Ratios } \\
\hline \multicolumn{4}{|c|}{$\begin{array}{c}\text { Current Policy } \\
\text { Tax Deductible Interest } \\
\end{array}$} & \multicolumn{2}{|c|}{$\begin{array}{lr}\text { Nondeductible Interest Expense } \\
\text { Scenario } 1 & \text { Scenario 2 } \\
\end{array}$} \\
\hline \multicolumn{2}{|c|}{ Equity Book Value } & $\$ 1,500.00$ & \multicolumn{2}{|c|}{$\$ 1,500.00$} & $\$ 1,500.00$ \\
\hline \multicolumn{2}{|c|}{ Tax Shield Value } & 0.00 & \multicolumn{2}{|c|}{0.00} & 0.00 \\
\hline \multicolumn{2}{|c|}{ Sticky Price Value } & 0.00 & \multicolumn{2}{|c|}{125.00} & 0.00 \\
\hline \multicolumn{2}{|c|}{ Amount of Debt } & 0.00 & \multicolumn{2}{|c|}{0.00} & 0.00 \\
\hline \multicolumn{2}{|c|}{ Total Value of Firm } & $\$ 1,500.00$ & \multicolumn{2}{|c|}{$\$ 1,625.00$} & $\$ 1,500.00$ \\
\hline \multicolumn{2}{|c|}{ Return on Equity } & $12.50 \%$ & \multicolumn{2}{|c|}{$12.31 \%$} & $12.50 \%$ \\
\hline \multicolumn{6}{|c|}{ Weighted Average } \\
\hline \multicolumn{2}{|c|}{ Cost of Capital } & $12.50 \%$ & \multicolumn{2}{|c|}{$12.31 \%$} & $12.50 \%$ \\
\hline \multicolumn{2}{|l|}{ Share Price } & $\$ 10.00$ & \multicolumn{2}{|c|}{$\$ 10.83$} & $\$ 10.00$ \\
\hline \multicolumn{2}{|c|}{ Earnings Per Share } & $\$ 1.25$ & & 1.33 & $\$ 1.25$ \\
\hline Debt Coverag & Ratio & NA & $\mathrm{N}$ & & $\mathrm{NA}$ \\
\hline $\begin{array}{r}\text { Notes: Shares } \\
\text { Op. } \\
\text { E. B } \\
\text { N. I }\end{array}$ & $\begin{array}{l}\text { outstanding } \\
\text { Pr. = Opera } \\
\text { Tax = Earn } \\
=\text { Net Incon }\end{array}$ & $\begin{array}{l}=150, \\
\text { ting Profit, } \\
\text { ings Before Tax } \\
\text { ne }\end{array}$ & $\begin{array}{l}\text { Int. Exp } \\
\text { E. A. Ta }\end{array}$ & $\begin{array}{l}=\text { Interest Exp } \\
x=\text { Earnings Af }\end{array}$ & $\begin{array}{l}\text { se, } \\
\text { Tax, }\end{array}$ \\
\hline
\end{tabular}


The capital structure of the company with average leverage, NORMCO, is $\$ 1000$ equity (S) and $\$ 500$ debt (B). The cost of borrowing is $10 \%$. The value of the tax shield (the tax rate multiplied by the amount of debt) is $\$ 125$. This results in an equity market value of $\$ 1125$. With 100 shares outstanding, the value per share is $\$ 11.25$. The ROE is computed using (3), and for NORMCO is $13.33 \%$. The cost of capital is computed using (4) and the result is $11.54 \%$. The financial data for NORMCO is presented in the first column of Table 2.

The company with high leverage, HILEVCO, has borrowed $\$ 1000$, has a book equity value of $\$ 500$, and a tax shield worth $\$ 250$. The market value of the equity is $\$ 750$. With 50 shares outstanding, the value per share is $\$ 15.00$. HILEVCO has a return on equity of $15.00 \%$ and a cost of capital of $10.71 \%$. Refer to the first column in Table 3 for the financial data of HILEVCO.

\section{Findings}

Next we examine these companies after the tax change using the two economic scenarios outlined above: sticky prices and perfect competition. After the tax code change, we compute taxes after deducting operating costs. These operating costs are equal for the three firms since they differ only in capital structure. We reduce the tax rate from $25 \%$ to $20 \%$ in the first scenario and to approximately $21 \%$ in the second scenario to achieve tax revenue neutrality.

In the first scenario, we assume a non-competitive environment. In this environment, prices are sticky and do not change after we reduce the tax rate. Since prices do not change, total corporate sales and total earnings will be the same as under the current tax policy (the base case). While the totals remain the same, the no-leverage firm receives an earnings increase, the high-leverage firm and equal earnings decrease, and the average-leverage firm has constant earnings.

The middle column of Table 1 shows the financial impact of the tax change under scenario one for NOLEVCO. The tax bill of the firm decreases from $\$ 62.50$ to $\$ 50.00$, increasing earnings by $\$ 12.50$. Treated as a perpetuity and discounted at the risk free rate of $10.00 \%$, this addition to earnings will add $\$ 125$ to the value of the firm. In the MM analysis, the present value of the tax shield is computed by discounting at the risk free rate. We use the same logic here to compute the present value of a stream of excess profits. The $\$ 125$ added value, recorded in the sticky-price value row of Table 1, also will apply to the other two firms under the first scenario. The effect of these windfall profits is to reduce the discount rate applicable to the firm (and the ROE) to $12.31 \%$. This rate can be found by dividing the earnings by the value of the firm $(\$ 200 / \$ 1625)$.

Perfect competition is the assumption in the second scenario. Competitive pressures from firms with below average leverage would lead to price cuts rather than windfall profits. If we assume that costs and unit volume remain constant, tive pressures from firms with below average leverage would lead to price cuts rather than windfall profits. If we assume that costs and unit volume remain constant, then sales revenue decreases by the amount of the price cut. We show 
Table 2

NORMCO Financial Data

\begin{tabular}{|c|c|c|c|c|c|}
\hline \multicolumn{6}{|c|}{ Income Statement } \\
\hline \multirow{2}{*}{\multicolumn{2}{|c|}{$\begin{array}{c}\text { Current Policy } \\
\text { Tax Deductible Interest }\end{array}$}} & \multicolumn{4}{|c|}{ Nondeductible Interest Expense } \\
\hline & & \multicolumn{2}{|c|}{ Scenario 1} & \multicolumn{2}{|c|}{ Scenario 2} \\
\hline Sales & $\$ 1,0000.00$ & Sales & $\$ 1,000.00$ & Sales & $\$ 987.50$ \\
\hline Costs & $(750.00)$ & Costs & $(750.00)$ & Costs & $(750.00)$ \\
\hline Op. Pr. & 250.00 & Op. Pr. & 250.00 & Op. Pr. & 237.50 \\
\hline Int. Exp. & $(50.00)$ & Tax (@20\%) & $(50.00)$ & $\operatorname{Tax}(@ 21 \%)$ & $(50.00)$ \\
\hline E. B. Tax & 200.00 & E. A. Tax & 200.00 & E. A. Tax & 187.50 \\
\hline $\operatorname{Tax}(@ 25 \%)$ & $(50.00)$ & Int. Exp. & $(50.00)$ & Int. Exp. & $(50.00)$ \\
\hline N. I. & 150.00 & N. I. & 150.00 & N. 1. & 137.50 \\
\hline \multicolumn{6}{|c|}{ Values and Ratios } \\
\hline \multicolumn{3}{|c|}{$\begin{array}{l}\text { Current Policy } \\
\text { Tax Deductible Interest }\end{array}$} & \multicolumn{3}{|c|}{$\begin{array}{l}\text { Nondeductible Interest Expense } \\
\text { Scenario } 1\end{array}$} \\
\hline \multicolumn{2}{|c|}{ Equity Book Value } & $\$ 1,000.00$ & \multicolumn{2}{|c|}{$\$ 1,000.00$} & $\$ 1,000.00$ \\
\hline \multicolumn{2}{|c|}{ Tax Shield Value } & 125.00 & \multicolumn{2}{|c|}{0.00} & 0.00 \\
\hline \multicolumn{2}{|c|}{ Sticky Price Value } & 0.00 & \multicolumn{2}{|c|}{125.00} & 0.00 \\
\hline \multicolumn{2}{|c|}{ Amount of Debt } & 500.00 & \multicolumn{2}{|c|}{500.00} & 500.00 \\
\hline \multicolumn{2}{|c|}{ Total Value of Firm } & $\$ 1,625.00$ & \multicolumn{2}{|c|}{$\$ 1,625.00$} & $\$ 1,500.00$ \\
\hline \multicolumn{2}{|c|}{ Return on Equity } & $13.33 \%$ & \multicolumn{2}{|r|}{$13.33 \%$} & $13.75 \%$ \\
\hline \multirow{2}{*}{\multicolumn{2}{|c|}{$\begin{array}{l}\text { Weighted Average } \\
\text { Cost of Capital }\end{array}$}} & & \multirow{2}{*}{\multicolumn{2}{|c|}{$12.31 \%$}} & \\
\hline & & $11.54 \%$ & & & $12.50 \%$ \\
\hline \multicolumn{2}{|l|}{ Share Price } & $\$ 11.25$ & \multicolumn{2}{|c|}{$\$ 11.25$} & $\$ 10.00$ \\
\hline \multicolumn{2}{|c|}{ Earnings Per Share } & $\$ 1.50$ & \multicolumn{2}{|c|}{$\$ 1.50$} & $\$ 1.38$ \\
\hline \multicolumn{2}{|c|}{ Debt Coverage Ratio } & 5.00 & & 4.00 & 3.75 \\
\hline \multicolumn{6}{|c|}{$\begin{array}{l}\text { Notes: Shares outstanding }=100, \\
\text { Op. Pr. = Operating Profit, } \\
\text { E. B. Tax = Earnings Before Tax, } \\
\text { N. I. = Net Income }\end{array}$} \\
\hline
\end{tabular}


Table 3

HILEVCO Financial Data

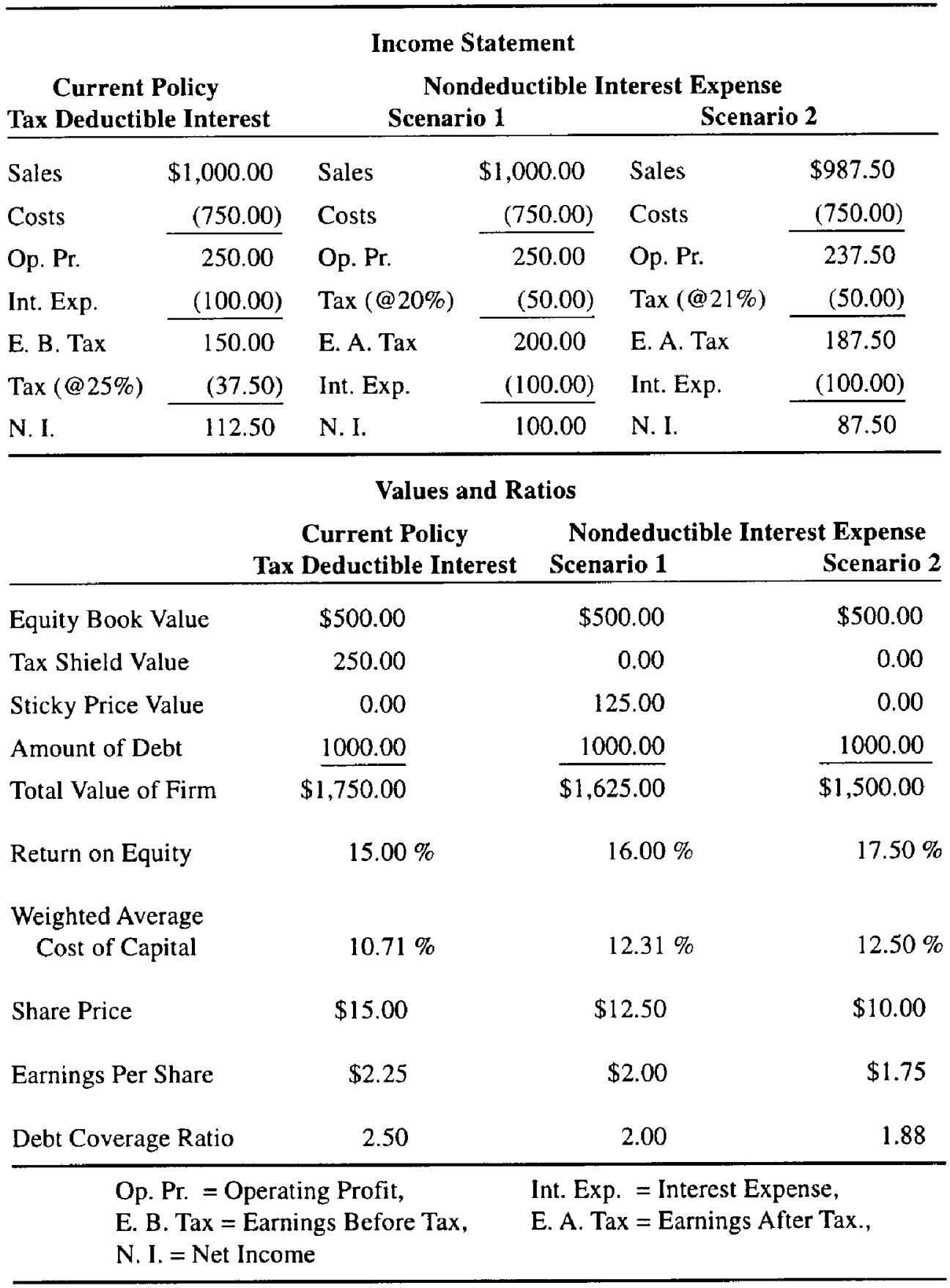


NOLEVCO's financial results for the second scenario in the third column of Table 1. In this scenario, NOLEVCO's earnings remain at the original $\$ 187.50$ level and the firm's discount rate remains at the base case rate of $12.50 \%$. The share price that increased in the first scenario to $\$ 10.83$ due to the windfall increase in earnings, returns to the original level of $\$ 10$ in the second scenario. There are no windfall benefits for the firm, and we assign zero value the stickyprice value row. The tax change would not affect the stockholders of this firm under scenario two.

We present the post-tax change financial information for NORMCO in column two and three of Table 2. In scenario one, the firm looses the value of the tax shield $(\$ 125)$ but gains an equal benefit from sticky prices. The WACC increases to $12.31 \%$, the same as the discount rate of the unlevered firm under windfall profits. The values of the levered and unlevered firm have to be equal when there is no tax shield. This result is consistent with the theory of MM. The way this happens under the first scenario is for the sticky-price value to apply to the levered as well as the unlevered firm.

In the second scenario, competition from the unlevered firm causes prices to decrease and NORMCO will experience a $\$ 12.50$ reduction in earnings. Since the value of the tax shield has been lost and there is no benefit from sticky prices, the value of the firm is the same as the value of the unlevered firm. The share price falls to $\$ 10$, the same price as the unlevered firm.

Column two and three in Table 3 shows the financial data for HILEVCO after the tax change. Because HILEVCO has above average leverage, the tax change will cause a reduction in earnings in both scenarios. The reduction in earnings in the first scenario equals the gain realized by NOLEVCO. In scenario one, value is transferred from firms with above average leverage to firms with below average leverage. The loss in stockholder value by HILEVCO is equal to the gain in NOLEVCO stockholder value. In the second scenario, HILEVCO share price declines to $\$ 10.00$, the same as the other two firms.

In Tables 1 through 3 the share prices, earnings per share (EPS), and ROE are consistent with the MM propositions. In scenario two, we have the situation where all firms have the same WACC and share price. The EPS and ROE increase with leverage to reward the stockholders for exposure to financial risk.

To maintain the MM result under the second scenario, the present value of the price reduction must equal the present value of the tax shield. The total value of the tax shields of the three firms is $\$ 375$; NOLEVCO $\$ 0$, NORMCO $\$ 125$, and HILEVCO $\$ 250$. The price cut (reduction in revenue) is $\$ 12.50$ per firm, or $\$ 37.50$ in perpetuity. Using the risk free rate of $10 \%$, the present value of this perpetuity is $\$ 375$. The loss in value to the stockholders is redistributed to the consumer. The consumer would receive a price reduction of $1.25 \%$ under perfect market conditions. Goods that previously cost $\$ 1,000$ would now cost $\$ 987.50$.

We also show debt coverage ratios in Tables 1 through 3 . The debt coverage ratio decreases when interest payments are no longer tax-deductible. Bondhold- 
ers would hold securities that are subject to a somewhat higher risk of default because the priority of the bondholders' claim has been reduced as a result of the change. This would adversely effect the market price of the bonds and require the company to make higher coupon payments when debt is issued in the future. Since we are assuming risk free debt we will not attempt to model the effect of the decrease in the coverage ratio.

\section{Size of the Redistribution}

As Cutler (1988) and Downs and Tehranian (1988) point out, it is very difficult to estimate the impact of tax policy changes on the stock market. We use the MM methodology to estimate the maximum impact that changing the deductibility of interest expense would have on stock prices. According to the Federal Reserve Board, the amount of corporate borrowing outstanding in the U.S. at the end of 1995 was $\$ 2,849$ billion. If we use an effective tax rate of $25 \%$ and assume $\mathrm{tD}$ from (1) holds for risky debt, then the maximum value of the tax shield would be $\$ 712$ billion. A reduction of this size in the market value of corporate stock would approximate the stock market crash of October 1987.

Several factors diminish the actual value of the tax shield. If stockholders discount the value of the tax shield because of its problematic nature, then this would reduce its value, and the actual impact on stockholder wealth would be considerably diminished. In addition, the growing impact of the alternative minimum tax has reduced the value of all tax preference items and would reduce the value of the tax shield if the firm has tax deductions it can not currently use. The nature of the tax law change could also reduce the impact on shareholders. For example, if the corporate tax is replaced by a VAT or national sales tax then the corporate deferred tax liability would be eliminated, and the balance of this account would be transferred to retained earnings and would increase stockholder book value. This would increase shareholder wealth and offset the loss of the tax shield. Givoly and Hayn (1992) estimate that investors treat the deferred tax liability as if it were worth 40 or 50 percent of the balance sheet value. Any policy change that reduces or eliminates the deferred tax liability would thus increase the value of the firm for the shareholder. The flat tax proposal of Hall and Rabushka (1983) would incorporate other changes that would tend to increase the value of corporate securities. These changes include the elimination of the capital gains tax and taxes on interest and dividend income.

\section{Summary and Conclusions}

\section{Summary}

This paper considers a tax policy alternative that would eliminate the interest expense as a tax-deductible item for U.S. businesses. We examine this policy change in a tax-revenue neutral setting. This results in a decrease in tax rates since taxable income is increased. We use two assumptions concerning economic 
markets and compare the results to the present corporate tax code. Scenario one assumes that prices are sticky and would not change because of a change in the tax code. Scenario two assumes that competition by companies with low leverage would lead to reduced prices instead of excess profits. The new tax policy would have the following results under scenario one:

1. Total corporate earnings would remain constant under constant sales.

2. Unlevered firms and firms with less than average leverage would enjoy increased EPS. Firms with greater than average amounts of debt would have lower EPS. The average firm would have constant EPS. This will result in a transfer of wealth from the shareholders of firms with above average leverage to the shareholders of firms with below average leverage.

3. For all levered firms the value of the debt tax shield is lost.

4. All firms will receive an increase in value based on the size of the extra earnings received by the unlevered firm due to the tax rate decrease and sticky prices. In the case of firms with below average leverage, the value of the windfall profits could exceed the loss of the debt tax shield.

Under the perfect-competition conditions of scenario two, the following would occur:

1. If unit demand is constant, total corporate sales and earnings would decrease as a result of price reductions.

2. Unlevered firms would have the same EPS as under the present tax policy. All levered firms would experience a decrease in EPS and a loss in value.

3. The loss of value for the stockholders of levered firms is greater than under scenario one due to the loss of the tax shield and no benefit from sticky prices.

4. Consumers receive a transfer in wealth from shareholders, in the form of lower prices whose present value is equal to the present value of the lost tax shields.

Under either scenario the following will occur:

1. Corporate debt would become more risky due to the reduction in priority of payment.

2. The WACC would increase to the discount rate appropriate to the riskiness of earnings stream. The average cost of capital would therefore increase. Leverage is still able to increase the risk and return on equity capital, but will not lower the WACC.

Which is the more likely scenario? The answer to this question could vary from industry to industry depending on the degree of competition present in the industry. In highly competitive industries with generic products, the result should approximate scenario two. In less competitive industries, the result would approach scenario one. 


\section{Implications for Managers and Policy Makers}

The results that we show in our analysis have important strategic implications for decision makers. The Tax Code is a significant factor in the business environment. A change that eliminates the tax deductibility of business interest expense will have several impacts on businesses. According to MM, an immediate impact would be the loss of the value of the tax shield. The loss of the tax shield will have a greater impact on highly levered firms and cause decreases in the value of these firms. In the example we use above, the stock price of the highly levered firm went from $\$ 15$ to $\$ 10$. This was under perfect market conditions in an industry where an unlevered firm will set product prices.

In the real world we would not expect to see such large changes. All firms use some leverage and perfect market conditions do not hold. However, our results lead us to predict that firms with relatively high amounts of debt in their capital structure would restructure to lower levels of debt if the proposed tax change had a high likelihood of being implemented. This type of restructuring could have enormous implications for the capital markets since large amounts of debt would probably be retired by raising additional equity capital. A simultaneous change that makes dividend income non-taxable for investors would make it easier to raise equity capital and reduce the upward pressure of the cost of capital.

\section{References}

Copeland, T. and F. Weston. Financial Theory and Corporate Policy. 3rd ed. New York: Addison-Wesley, 1988.

Cutler, D.M. "Tax Reform and the Stock Market: An Asset Price Approach." The American Economic Review 5 (1988): 1107-1117.

Downs, T.W. and H. Tehranian. "Predicting Stock Price Responses to Tax Policy Changes." The American Economic Review 5 (1988): 1118-1130.

Jorgenson D.W. and K.Y. Yun. Tax Reform and the Cost of Capital. Oxford: Clarendon Press, 1991.

Givoly, R. and C. Hayn. "The Valuation of the Deferred Tax Liability: Evidence from the Stock Market." The Accounting Review (Apr. 1992): 394-410.

Hall, R. and A. Rabushka. Low Tax. Simple Tax. Flat Tax. New York: McGraw Hill, 1983.

Masulis, R. The Debt/Equity Choice. New York: Ballinger Publishing Company, 1988.

Modigliani, F. and M. Miller. "The Cost of Capital, Corporation Finance, and the Theory of Investment." American Economic Review (June 1958): 261-297. 
"Corporate Income Taxes and The Cost of Capital: A Correction." American Economic Review (June 1963): 433-443.

Poterba, J.M. "Why Didn't the Tax Reform Act of 1986 Raise Corporate Taxes?" Tax Policy and the Economy 6 (1992): 43-58.

Sinn, H.W. "Taxation and the Cost of Capital: The "Old" View, the "New" View, and another View." Tax Policy and the Economy 5 (1991): 25-54.

Scholes, M. and M. Wolfson. Taxes and Business Strategy. A Planning Approach Practice. Englewood Cliffs, NJ: Prentice Hall, 1992.

Slemrod, J. and M. Blumenthal. The Income Tax Compliance Cost of Big Business. Washington, DC: Tax Foundation, 1993.

Sullivan, M. Flat Taxes and Consumption Taxes: A Guide to the Debate. New York: American Institute of Certified Public Accountants, 1995.

William Lewis Randolph, (Ph.D., University of Alabama) is an Associate Professor of Finance at Norfolk State University where he teaches courses in corporate finance and investments. He is also Managing Editor of the Journal of Developmental Entrepreneurship. He received his Ph.D. in 1986. He is a former Navy carrier pilot whose last assignment in the Navy was Commanding Officer of Training Squadron Nineteen. His major research interests include options, after-tax investment returns, and developmental entrepreneurship. Professor Randolph is a Chartered Financial Analyst. His consulting areas include securities arbitration and litigation and security analysis. 